\title{
Research of the Technological Future's Uncertainty
}

\author{
J. Kovalchuk, I. Stepnov \\ Financial University under the Government of the Russian Federation \\ Moscow Aviation Institute (National Research University)
}

Review of the books: Franklin D. Megatech:Technology and Society: 2050 in the Forecasts of Scientists and Writers. Moscow, Bombora, 2018. 400 p. (in Russian) Leonghard G. Technology vs. Humanity: The Coming Clash between Man and Machine. Moscow, Publishing house AST, 2018. 260 p. (in Russian)

Keywords: digital economy, technological breakthrough, technologies of the future, virtual reality, Moore's law, artificial intelligence, humanism, risks.

$\mathrm{P}$ redicting the technologies which will be available in the near future is an extremely popular activity, as the development of mankind is undeniably associated with technological achievements: the first fire, the wheel, the steam engine, electricity, the laser, personal computers, the Internet, robotics... This list can be continued indefinitely, especially at a time when the foundations of human life are undergoing a technological transformation, called «universal digitalization».

These changes do not happen simply, and happen very quickly (science-fiction writers have even proposed calling this period «accelerando» (ital. accelerando), a musical term indicating the gradual acceleration of the musical work's tempo, especially at its end (Stross 2005), and compare its importance with the industrial revolution of the middle of the 18th century); evidence of this is, for example, the spread of the Internet 30 years after its appearance ${ }^{1}$ it is used by more than $50 \%$ of the world's population, and over the past 5 years the number of users has increased by $75 \%$ to almost 2 billion people who make online purchases, book hotels and plane tickets, etc. According to the International Telecommunication Union ${ }^{2}$, it took 16 years to reach the first billion

УДК: 327.8

Received: August 1, 2019

Accepted: October 8, 2019

\footnotetext{
1 The Birth of the Web. CERN. Available at: https://home.cern/science/computing/birth-web

2 Statistics. International Telecommunication Union (ITU). Available at: https://www.itu.int/en/ITU-D/Statistics/Pages/ stat/default.aspx (accessed 22.12.2019)
} 
Internet users. The second billion joined the network in just 6 years. Today, the Internet is growing at a rate of 1 billion new users in 2.7 years.

It is not the Internet alone, however, that can characterize the impact of technology on society and the economy. In their most precise essence, technologies should be considered through the original Greek term «techne», which means «revealing the true in the beautiful» and refers to the improvement of the skills of artisans and artists with the help of appropriate tools (Barrat 2013). Technology has always played a catalytic role in the socio-economic development of countries - as it did in the distant past, and so, obviously, will do in the future. Theoretically, this is proved through the concept of long waves by N. Kondratiev, macroeconomic model by R. Solow, technological structures by S. Glazyev, and others. In 2018 the Nobel Prize in Economics was awarded to P. Romer for macroeconomic research on the impact of technological innovations on long-term economic growth and research, as economic solutions and market conditions determine the development of new technologies, and the willingness of firms to create new ideas and innovations draws the attention of the scientific community to the problems of finding incentives for technological breakthroughs. Therefore, in modern conditions, the competitiveness of countries is actually determined by their technological leadership (it is very useful here to recall the phrase of former Israeli President Peres: «... now the economy is more based on science and technology. There is practically no value either in the territories or in the borders.... ${ }^{3}$ ), and, accordingly, each country's task of seeing the technological future for its economic growth is important and urgent.

What will these technologies of the future be like? Consider two books that, over the past two years, have provoked another wave of discussions about the development of science and technology.

The first book «Megatech: Technology, and Society in 2050 in the Projections of Scientists and Writers» (hereinafter "Megatech») was written by the editor of «The Economist» Daniel Franklin, from projections made by the world's leading scientists, Nobel laureates, and writers. This is not his first work in this direction - in 2012 he published the book «The World in 2050» («Megachange: the World in 2050», 332 pages) in the format of an overview of global trends in areas such as demography, health, culture, economy, etc. It is obvious, however, that the identified trends and technology were a significant impacted, thanks to which the idea of a new book emerged, focusing on the technologies of the future.

The second book «Technology vs. Humanity: The Coming Clash between Man and Machine» was written by Gerd Leonard, a Swiss futurist and one of the best European experts on technology publications such as the New York Times, Guardian, Forbes, Business Insider. In this book, the author shares his thoughts on the subject of uncontrolled use of innovations, and what harm they can bring to society.

\footnotetext{
3 Peres Sh. Reversal. Interview, 06 September 2006. Available at: https://echo.msk.ru/programs/razvorot/45992/ (accessed 22.12.2019) (In Russian).
} 
The comparison of these two books makes it possible to distinguish two opposing views on the prospects of mankind: the first takes and optimistic view on the technological future, whilst the second considers the future of mankind from various, less optimistic standpoints, such as the need and humanity of technological development, and the human right for privacy in the modern world's digital society.

In any case, technology should serve humanity, but over many years technology and humanity may be further transformed. Therefore, in order to more objectively evaluate these two books, we consider the main tasks and problems posed in them.

The logic of «Megatech» is built around Moore's law and its limitations in modern reality - this is most detailed in section 4 «Beyond Moore's law» (author T. Cross). G. Moore, one of the founders of Intel, revealed a pattern occurring since 1965 (6 years after the invention of the integrated circuit): the number of transistors placed on the chip doubles every 2 years, and on the processor power every 1.5 years. Now that the chips are microscopic in size and their further miniaturization becomes extremely easy to do, Moore (Moore 2003) and other experts agree that Moore's law will no longer work. «Since the launch of the microprocessor 4004 in 1971, until mid-2016, 22 cycles of Moore's law were passed. Until 2050, 17 cycles are still supposed to happen. And in the last of them, experts will have to figure out how to assemble computers from components smaller than a hydrogen atom - the smallest of the existing natural elements. That, as far as we know, is impossible» (p. 87). At the same time, it is true that even if Moore's law will not work, the improvement of computer technology and everything connected with it will not be stopped - in 2050 a computer will consist of tiny chips, whilst all living and inanimate beings will be chipped to create systems of communication linking people and machines and creating the ability to process huge amounts of information data. The Google Technical Director R. Kurzweil predicts, more extremely, that in 2025 computers will surpass the computing power of the human brain, and in 2050 a single computer will surpass the thinking power of all people combined ${ }^{4}$.

Data (or information) are considered in «Megatech» as «fuel» (p. 233) of new technological developments, which will be improved by 2050, as it was in the 19th century with a steam engine, in the 20th century with electricity and oil (although it should be noted that information is not yet knowledge!). Therefore, in addition to the development of computer technology, Megatech also considers artificial intelligence (section 5 «Technology generations: the past as a prologue», author E. Winblad) with the example of Uber, the company created in 2009 which became an innovator in the creation of a digital platform for taxi orders and generator of income for drivers. Uber, according to the author, is a company «working with big data» (p. 112), when a potential customer uses a multi-core smartphone with geolocation and a payment system, and the driver can adjust the route based on the linear data or the transport situation,

\footnotetext{
4 Kurzweil Raymond. Available at: https://ru.wikipedia.org/wiki/Курцвейл,_Рэймонд\#Ссылки (accessed 22.12.2019) (In Russian).
} 
so artificial intelligence has benefited the company, improving business and attracting new customers by regulating supply and assessing market demand for the price of the trip.

However, it is difficult to agree with this mere conclusion - the real problem of this company is high costs (up to $58 \%$ of the trip price ${ }^{5}$ ) for drivers, and the task is an objective desire to reduce them and make a profit, as the company suffers losses - about $\$ 3$ billion in $2018^{6}$. Therefore, despite competition (among major automakers such as Volkswagen, General Motors, Jaguar Land Rover, Toyota, Audi, BMW, etc., and also the IT giants Google and Apple), Uber is involved in the design of a new market for self-driving taxis (i.e. actually unmanned vehicles), for which an IPO (eng. Initial Public Offering - initial public offering) was held on May 9, 2019 on the NYSE, which was among the three largest in the history of the US stock market (following Facebook in 2012 and Alibaba in 2014) ${ }^{7}$.

In general, modern companies are faced with a set of tasks: a) the classic need to reduce operating costs (for example, drivers require higher tariffs, reduce service fees by $15-25 \%$, and increase wages on weekends and holidays); b) the creation of a reserve for the future, providing competitive advantages - these guaranteed a successful future via new technologies and equipment. Unmanned vehicles, according to the Boston Consulting Group $(\mathrm{BCG})^{8}$, in a few decades will allow humanity to reduce the accident rate by $70 \%$ and save about $\$ 1$ trillion, but they also have significant drawbacks: first, purely technical - the reliability of the software and the model of the behavior of the machine in the inevitable collision; second, legal - liability for damage. It is hard to explain why, in «Megatech», there is no mention of these problems.

It should be noted that the book «Megatech» is too optimistic - most likely, its results are provided by the targeted selection of technologies for consideration, which is not justified, not focused on the future, and is limited only to the already become a common set of modern technologies (biotechnology, artificial intelligence, virtual reality, unmanned vehicles, renewable energy sources, etc.). This approach becomes a significant drawback of the book; due to this it is inferior, for example, to the list of technologies presented in the book of the President of the World Economic Forum, K. Schwab's «Technologies of the fourth industrial revolution» (Schwab, Davis 2018), where the main technological drivers of new industrial development are systematized: a) digital technologies (new computing technologies, blockchain and distributed Ledger technologies, Internet of Things); b) technologies for transforming the physi-

\footnotetext{
5 Aryanova T. Why Uber suffers billions of dollars in losses. Available at: https://ru.insider.pro/investment/2017-01-10/ pochemu-uber-terpit-mnogomilliardnye-ubytki/ (accessed 22.12.2019) (In Russian).

${ }_{6}$ Uber has compared its output to the stock exchange for the IPO of Google and Facebook. Oh, nothing. RBC: Economics of innovation. Available at: https://quote.rbc.ru/news/article/5ce24b7a9a794782789fe44c (accessed 22.12.2019) (In Russian).

7 Uber held an IPO with an estimate of $\$ 82$ billion - one and a half times lower than forecasts. Available at: https://rb.ru/ news/uber-ipo/ (accessed 22.12.2019) (In Russian).

8 Unmanned vehicles. Market conditions, trends and prospects. Internet of Things News. Available at: https://iot.ru/ transportnaya-telematika/bespilotnye-avtomobili-sostoyanie-rynka-trendy-i-perspektivy-razvitiya (accessed 22.12.2019) (In Russian).
} 
cal world (artificial intelligence and robots, advanced materials, additive manufacturing and multidimensional printing); c) technologies for human change (biotechnology, neurotechnology, virtual and augmented reality); d) technologies for integrating the environment (generation, accumulation and transfer of energy, geo-engineering, space technologies). Despite the above drawback, it is necessary to specify that in «Megatech» there is a section devoted to military technology (section 13). It is obvious that technology penetrates not only into society, but also was a tool of speculative manipulation and almost always a trend of success in conquests that today have gone from territorial to global - this is expressed not only in new developments of weapons and military equipment, but also in the emergence of digital wars that use «digital weapons» suppression of the best human qualities.

An overview of the technologies in the «Megatech» is presented in a sequel, focusing on evolutions in the field as were known at that moment of time, without attempting to identify a potential future that allows the cementing of the conclusion that the first book («Megatech») did not fully correspond to loudly enough about the future because in most of the sections a summary of the trends of the present time is presented, as opposed to over 30 years. The most striking example is Virtual Reality Technologies presented in Chapter 12 «Personal technologies become really personal» (author L. Mirani). According to the author, in 2050 there will be a «giant leap forward» when «virtual and augmented reality will merge so that the transition between them will become invisible... Over time, the technology is getting closer to our bodies - eventually it will find a way to get inside them. Start putting in contact lenses. The technology associated with them already exists, however, so far it is only in rudimentary form. But in 2016, Samsung applied for a patent for smart contact lenses. They are very close to such a simple operation as replacing the lens of the eye with its technologically more advanced version» (p. 212). It should be noted that a breakthrough in virtual reality (VR) was predicted in the 1980s, but then the technology was quite expensive and primitive. VR is a computer simulation of a certain space in which a person-user is immersed through the impact on the receptors (vision, hearing, smell, tactility) by means of VR-devices (helmet, various motion sensors and controllers). At the same time, if VR implies a complete replacement of what the user sees in front of them, then augmented reality (AR) integrates virtual models into the real world (for example, a mega-popular Pokemon Go Game, or the makeup application Makeup Genius from L'Oreal). The first VR-machine «Sensorama», created in 1962, allowed people to watch movies, whilst smelling or feeling. Next, the flight simulator Super Cockpit was developed, a Data Glove glove equipped with sensors that tracks the movement of the hand and implements the functions of a controller for controlling computers and video games, and later used in tele-surgery. The most famous VR device was the helmet, but its main drawbacks were the narrow field of view and high cost (about $\$ 60$ 70 thousand). After its leading developers faced bankruptcy (in the mid-1990s), VR was forgotten for about 20 years, and now it is experiencing a new wave of popularity, but not effectiveness - the mass introduction of this technology has not been reached. 
The reason, as before, lies in the design features of VR devices and the complexity of virtual content.

The scope of VR-technologies mentioned in the book «Megatech» is quite limited, but today there is a real revival of this business trend: 1) the angle of view has been expanded to $110 \mathrm{o} ; 2$ ) the cost of the helmet with its necessary equipment is about \$ 800 from market leaders PlayStation VR, \$ 1376 from Oculus Rift; Goldman Sachs analysts, for example, predict its decline in the next few years ${ }^{9}$; 3 ) more widespread VR accounts for media formats (video games, TV broadcasting, training, training), but there are already successful results in other areas: industry (3D-modeling, prototyping, technological training), marketing (collection of a set of goods, interior design, service), medicine (simulators for training doctors, rehabilitation of patients, abandonment of bad habits), services (selection of objects for the purchase or lease of real estate), criminology (reconstruction of crime scenes), etc. However, it should also be noted that experts seriously consider the effects of «digiphrenia» (Rushkoff 2013) as a mental disorder, when technology forces a person to be in more than one place at the same time, and of the «Faust transaction», when a person actually sells his personal data in exchange for free use of social networks.

Why, according to Stendage (one of the authors, of section 1 «Set of Tools for Predicting the Future»), did the authors of «Megatech» not more constructively assess the prospects for developing these selected technologies, but limited themselves only to four promising areas: virtual reality, unmanned vehicles, private space and genetic engineering? This approach itself is rather controversial: «tips can be found in the laws of the past, in the «extreme cases» of the present, and in various versions of the «imaginary future» of science fiction» (p. 11). To assess the past in private space or unmanned vehicles is, however, quite difficult - there is no past, but the present. As stated in the title of the book, forecasts, obviously, do not have the full signs of reliability and verifiability.

Given that the authors of «Megatech» make predictions far ahead, in our opinion it would be necessary to assess the technologies that are still in the design stage and their result is not yet defined; the UK academics at Imperial Tech Foresight did and presented this in 2018 as the periodic table of breakthrough technologies ${ }^{10}$, by analogy with the Mendeleev's table, where 100 elements were equal to 100 breakthrough technologies of the future, distributed into four color categories depending on the probability of their implementation:

- 16 green elements - technologies that are currently being implemented or will soon be available (cryptocurrencies, autonomous cars, solar energy, artificial meat, wireless power transmission, etc.).);

\footnotetext{
9 Virtual reality. How VR is used in business and media. Available at: https://blog.dti.team/virtualnaya-realnost/?utm source=telegram\&utm_medium=social (accessed 22.12.2019) (In Russian)

${ }_{10}$ Wilson J. From the future of food to workplace Al: exploring tech that will shape future. Available at: http://www.imperial.ac.uk/news/186688/from-future-food-workplace-ai-exploring/ (accessed 22.12.2019).
} 
- 33 yellow elements - technologies (actually experimental developments) with potential distribution in the next 10-20 years (unmanned vehicles, water extraction from air, smart dust, 3D printing of human organs, etc.).);

- 32 red elements - technologies that exist conceptually and the introduction of which will be no earlier than 20 years (four-dimensional materials, implant phones, colonization of other planets, combat robots with artificial intelligence, etc.);

- 19 gray elements - technology, theoretically feasible, with a low probability of embodiment (head transplant, space elevator, etc.) ${ }^{11}$.

The second peer-reviewed book «Technologies vs. Humanity» is entirely devoted to assessing the risks that present and future technological changes may present not only on man, but also on human nature, which also requires predictions of future technologies.

G. Leonghard notes that «technology will trigger such mega-exploits that will work together and can change not only the economy, culture and society, but also our nature and morality» (p. 12) and that «finally we have reached a point where humancentered policies and standards, digital ethics, social contracts, and global agreements on the humanization of these exponential technologies will be as important as treaties on the non-proliferation of nuclear weapons» (Chapter 12).

In contrast to «Megatech», the second book seems to be based on more pessimistic and less technologically-focused ideas, and presents a more comprehensive and interesting comparison of the technologies of today and tomorrow, which the author defines as exponential (in accordance with the action of the abovementioned Moore's Law), with combinatorial effects when changes are mutually reinforcing and develop according to the principle of «gradually, and then immediately»: "Gradually we will begin to notice faint omens of great opportunity or great threat. And then they either suddenly disappear, or they stay here, now and on a much larger scale than we thought. Solar energy, unmanned vehicles, digital currency, blockchain - it took a very long time for their development, but here they are, experiencing a huge rise. History teaches us that those who adapt too slowly or fail to foresee danger will have to bear the consequences» (p. 33). However, the author notes that while $90 \%$ of technologies bring positive results (for example, new technologies in solar batteries allow alternative energy to develop, and the Internet of Things contributes to the emergence of smart homes, smart cities, smart factories). However, it must be remembered that about $10 \%$ of the risk and that the development of mankind and technology is now at the point of bifurcation, and it is important not to lose the chances to influence the future of mankind.

Of course, engineers are more pragmatic in relation to technology than humanitarians. After all, in the 16th century, Rene Descartes initiated the identification of animals with machinery, and then the man began to be seen as a complex system - a de-

\footnotetext{
11 Imperial College London. Table of Disruptive Technologies. Available at: https://www.imperial.ac.uk/media/imperialcollege/administration-and-support-services/enterprise-office/public/Table-of-Disruptive-Technologies.pdf (accessed 22.12.2019).
} 
vice that can be repaired (and even reproduce). In his interview, Leonghard also notes different interpretations of the concept of human development around the world: for example, Americans consider any problem purely technically and look for solutions to circumvent nature; Europeans understand that success in health care and life extension alone is not enough - a sense of happiness is needed; and the Chinese need state management of these processes ${ }^{12}$. Therefore, the author of the book as a whole comes to the conclusion that «technology is not evil or good, they just are. It is up to us to determine, here and now, how technology can be used for good and how to avoid its use for evil» (p. 118).

Leonghard persistently promotes the idea of digital ethics in the book (Chapter 10): «technology has no ethics, but humanity depends on them». In his opinion, which is difficult to disagree with, human ethics develop linearly in contrast to technologies that develop exponentially, and a society with unlimited powers of technological progress without ethics is doomed. Therefore, now, in the period of a boom in active investment in artificial intelligence technology, it is necessary to approach the problem of trained machines very seriously, so that people do not become useless, slow, or lazy without technology. On the other hand, the author emphasizes that machines, even if they learn to read, reproduce and understand human morality, are unlikely to be able to show empathy and have an identity: «Theoretically, they will be able to learn to behave like people. However, simulation is not the same as duplication, mediated reality is not reality itself» (p. 41).

In Leonghard's book there are several completely innovative provisions that can initiate new directions in science and practice; for example:

- definitions of megachanges in society as a results of the collision of man and machine, which includes 10 areas: the transition to digital and mobile devices, scarification, elimination of intermediaries, automation, virtualization, robotics, digital predictors;

- the introduction of the term «digital obesity» (Chapter 7), denoting a new pandemic, the essence of which is "overeating technology», which clearly reflects the reality of the binding of modern man to the already widespread info-communication technologies and mobile devices;

- the manifestation of exponential humanism, which will allow people to «accept the development of technology, but not to become them, and use them as a means, not as a goal» (p. 34). Therefore, it is necessary to invest not only in technological development, but also in the person himself;

- objective expediency of inclusion in Maslow's Pyramid of Needs at the level of basic needs, along with food, housing, mobile devices and Wi-Fi;

- the emergence of the smartphone as the second brain of the person.

\footnotetext{
12 G. Leonghard - RBC: «In 10 years, all programmers will be unemployed.» Interview. Available at: https://www.e-vid.ru/ nauka-i-tekhnika/180519/gerd-leongard-rbk-cherez-10-let-vse-programmisty-stanut-bezrabotnymi (accessed 22.12.2019) (In Russian).
} 
Leonghard also pays attention to the socio-economic problems associated with technological development - namely: the disappearance of $50 \%$ of existing professions in the digital economy, the already proven decline in employment due to automation increasingly penetrating into production processes and services, and the uncertainty about $70 \%$ of the professions in demand in the future - which makes his book a complete and comprehensive study of the impact of modern technologies on humans.

A common drawback of the books is the lack of forecasts about the economic structure of the future, as well as the lack of economic estimates of the future. Part of these estimates are given in section 6 «the Great Dispute about Innovation» (R. Avent) in the book «Megatech», which refers to the research of R. Gordon (Gordon 2016) on the past and future growth of production efficiency in the United States. Thus, «electricity, cars, sewage and modern medicine have led to a rapid increase in productivity. But today, despite the spread of the Internet, smartphones, apps and bots, productivity and wages are growing at a disappointingly slow pace. In any case, the development of technology contributes to inequality and creates frustration» (p. 14). However, despite such pessimistic conclusions, practice shows the growth of indicators characterizing the efficiency of business in the new digital era (presented in section 5 "Generation of Technologies: the Past as a Prologue», author E. Winblad): when it reached its revenue of $\$ 1$ billion, Microsoft (founded in 1975) was 15 years old, Google (founded in 1998) 5 years (and for 15 years its revenue exceeded $\$ 50$ billion), and Facebook (founded in 2004) was 4 years old. The first company to overcome the mark of $\$ 1$ trillion capitalization was Apple (August 2018), and then Google Inc. (formerly Google).

In this regard, the authors' conclusions about the driving economic forces behind technology are very interesting. For example, «Megatech» notes that capitalism encourages new ideas and is an integral part of technological development, as it contributes to the creation of new products and obtaining a surplus. On the contrary, Leonghard announces the abundance of "everything" that the new industrial revolution will bring, and further states that this will contribute to the collapse of classical capitalism and the emergence of a new "post-capitalism". Open markets, not through an «invisible hand» but regulated by growth and profits, will inevitably exacerbate the problems between people and technology, «as the profits from the sale of the latter are estimated at trillions of dollars a year» (p. 33). And here, too, is the future, where technology plays a significant role.

In conclusion, we note that many publications on the subject of future technologies, as well as on the results of technological foresights, indicate a certain uncertainty about the future. As such this technology is the object of analysis not only in those areas of their application, but also in conjugate, which make it possible to not only physically and economically but also philosophically assess the scale of the movement of mankind in this new technological era with new opportunities. Finally, it is worth remembering that «the elevator breaks down more often than the ladder» and, in the 
words of Steve Jobs, the founder of Apple, the most expensive and one of the most high-tech companies of our time: «I would exchange all my technologies for an afternoon with Socrates» ${ }^{13}$.

\section{About the authors:}

Igor M. Stepnov - Doctor of Economics, Professor of Financial University under the Government of the Russian Federation. 49 Leningradsky Prospekt, Moscow, Russian Federation, 125993.

E-mail: stepnoff@inbox.ru.

Julia A. Kovalchuk - Doctor of Economics, Professor of Moscow Aviation Institute (National Research University). 4 Volokolamskoe shosse, Moscow, Russian Federation, 125993. E-mail: fm-science@inbox.ru.

\section{Conflict of interests:}

The authors declare absence of conflict of interests.

\section{Исследование неопределённости технологического будущего}

Ю.А. Ковальчук, И.М. Степнов

DOI 10.24833/2071-8160-2019-6-69-214-224

Финансовый университет при Правительстве Российской Федерации

Московский авиационный институт (Национальный исследовательский университет)

Рецензия на монографии: Франклин Д. Мегатех. Технологии и общество 2050 года в прогнозах учёных и писателей. Москва, Эксмо, 2018. 400 с.

Леонгард Г. Технология против человечества: грядущее столкновение между человеком и машиной. Москва, Издательство АСТ, 2018. 260 с.

Ключевые слова: цифровая экономика, технологический прорыв, технологии будущего, виртуальная реальность, закон Мура, искусственный интеллект, гуманизм, риски.

\section{Информачия об авторах:}

Игорь Михайлович Степнов - доктор экономических наук, профессор Финансового университета при Правительстве Российской Федерации. Ленинградский проспект, 49, Москва, Российская Федерация, 125993. E-mail: stepnoff@inbox.ru.

\footnotetext{
1310 great quotes from Steve Jobs. I would trade all of my technology for an afternoon with Socrates (Newsweek, 29 October 2001). Available at: https://edition.cnn.com/2012/10/04/tech/innovation/steve-jobs-quotes/ (accessed 22.12.2019).
} 
Юлия Александровна Ковальчук - доктор экономических наук, профессор Московского авиационного института (Национального исследовательского университета). Волоколамское шоссе, 4, Москва, Российская Федерация, 125993. E-mail: fm-science@inbox.ru.

\section{Конфликт интересов:}

Автор заявляет об отсутствии конфликта интересов.

\section{References:}

Barrat J. 2013. Our Final Invention: Artificial Intelligence and the End of the Human Era. New York: Thomas Dunne Books; St. Martin's Press. 336 p.

Gordon R. 2016. The Rise and Fall of American Growth. The U.S. Standard of Living since the Civil War. Hardcover. 784 p.

Moore G.E. 2003. No Exponential Is Forever: But »Forever» Can Be Delayed! Solid-State Circuits Conference, IEEE International Digest of Technical Papers. Vol. 1. P. 20-23. DOI:10.1109/ ISSCC.2003.1234194.

Rushkoff D. 2013. Present Shock: When Everything Happens Now. Penguin. 304 p.

Schwab K., Davis N., 2018. Nadella S. Shaping the Fourth Industrial Revolution. World Economic Forum. 289 p.

Stross Ch. 2005. Accelerando. Orbit books. 400 p. 